\title{
A Real-Time Energy Consumption Simulation and Comparison of Buildings in Different Construction Years in the Olympic Central Area in Beijing
}

\author{
Chen $\mathrm{Xu}^{1,2,3}$ (D), $\mathrm{Yu} \mathrm{Li}^{1,3}$, Xueting Jin ${ }^{1,3}$, Liang Yuan ${ }^{4}$ and Hao Cheng ${ }^{1, *}$ \\ 1 Institute of Geographic Sciences and Natural Resources Research, Chinese Academy of Sciences, \\ Beijing 100101, China; xuc.14s@igsnrr.ac.cn (C.X.); Liy@igsnrr.ac.cn (Y.L.); jinxt.15s@igsnrr.ac.cn (X.J.) \\ 2 Centre of Architecture Research and Design, University of Chinese Academy of Sciences, \\ Beijing 100190, China \\ 3 College of Resource and Environment, University of Chinese Academy of Sciences, Beijing 100049, China \\ 4 Graduate School of Engineering, Kyushu University, Fukuoka 819-0395, Japan; yuan.1.398@s.kyushuu.ac.jp \\ * Correspondence: chengh.12b@igsnrr.ac.cn; Tel.: +86-10-6488-9093
}

Received: 30 October 2017; Accepted: 29 November 2017; Published: 6 December 2017

\begin{abstract}
Energy consumed the in urban sector accounts for a large proportion of total world delivered energy consumption. Residential building energy consumption is an important part of urban energy consumption. However, there are few studies focused on this issue and that have simulated the energy consumption of residential buildings using questionnaire data. In this research, an eQUEST study was conducted for different residential buildings in the Olympic Central Area in Beijing. Real-time meteorological observation data and an actual energy consumption schedule generated by questionnaire data were used to improve the eQUEST model in the absence of actual energy consumption data. The simulated total energy consumption of residential buildings in the case area in 2015 is $21,262.28$ tce, and the average annual energy consumption per unit area is $20.09 \mathrm{kgce} /\left(\mathrm{m}^{2} \cdot \mathrm{a}\right)$. Space heating accounted for $45 \%$ of the total energy consumption as the highest proportion, and the second highest was household appliances, which accounted for $20 \%$. The results showed that old residential buildings, multi-storey buildings and large-sized apartment buildings consume more energy. The internal units, building height, per capita construction area, the number of occupants and length of power use had significant impact on residential energy consumption. The result of this study will provide practical reference for energy saving reconstruction of residential buildings in Beijing.
\end{abstract}

Keywords: residential building; energy consumption; eQUEST simulation; Beijing city

\section{Introduction}

Residential and commercial end users together accounts for $20.1 \%$ of the total delivered energy consumed worldwide. According to the IEO2016 Reference case, energy consumed in residential sector will be $13 \%$ of total world delivered energy consumption in 2040 [1]. China has been the world's largest energy consumer since 2010 [2]. The residential sector is China's second largest energy consumer [3], which accounted for $20.5 \%$ of the total energy consumption of the final consumption in 2014 [4]. In response to global climate change and energy demand, residential building energy consumption research in China has received extensive attention.

However, most of the methodologies used in existing residential building stock research lack accuracy. Residential end-use energy consumption could be divided into a top-down model and a bottom-up model [5]. Top-down models are easily to develop based on information provided by macroeconomic indicators. Various methods, such as cluster analysis, the classification analysis 
method [6] and the STIRPAT model [7] were used for top-down models. However, top-down models do not objectively show the actual energy consumption situation. Bottom-up models are considered relative more comprehensive. There is a growing interest in questionnaire survey. For example, Shan Hu et al. surveyed Chinese 31 cities' residential buildings in 2015, summarized the change trend of the energy consumption of residential buildings in these cities and analysed the relationship of energy consumption and energy use behaviours [8]. Iwan et al. promoted a questionnaire survey of 11 living areas in Indonesia and used a lifestyle analysis to calculate the construction of residential energy consumption [9]. This type of research was more concerned about the factors that influence the energy consumption and the energy consumption of the families in the area. However, few of them payed attention to the energy consumption of the public part of apartment buildings. Simulation tools, such as BIM [10], Visual DOE (version 4) [11], IDA-ICE [12], and TRNSYS [13] showed good performance. Among these sorts of software, eQUEST, which uses DOE-2's building description language (BDL), showed more practicability and convenience. It is in line with the U.S. LEED (Leadership in Energy \& Environmental Design Building Rating System) as the most commonly used tool for simulation coding [14]. eQUEST software simulation has been used in the research of energy consumption of the object from United States [15], Canada [16], South Korea [17] and China [18-21]. Further, the accuracy of the energy consumption simulation in the Olympic centre area has been verified by the simulation of the energy consumption in large public buildings in the case area [22]. The existing simulation tools mainly used standard climate data, focused on the simulation of a building's physical structure and lacked studies on the actual energy consumption behaviour of residents. The weather data change every year [23]. The use of real-time meteorological data to simulate the actual situation is considered to be an appropriate approach to building simulation applications [24] which can effectively improve the accuracy of energy consumption simulation and prediction [5]. Real-time meteorological data includes a full range of data, including dry bulb temperature, wet bulb temperature, wind speed, wind direction, relative humidity, solar radiation intensity, and air pressure [24]. What's more, occupant behaviours are varied, which greatly affect the energy consumption of residential buildings [5]. Different lifestyles of the residents lead to different energy consumption data [25]. Existing research showed that occupant behaviours had significant effect on space ventilation rates [26] and affected overall residential energy consumption forecast accuracy by $\pm 15-20 \%$ [27]. Therefore, we combine eQUEST simulation, questionnaires survey and incorporate real-time meteorological data to make the simulation results more accurate.

In order to simplify the calculation, it is necessary to classify the residential buildings in the study area according to the obvious classification factors. Firstly, the age of construction is an important basis for research. A research based on a survey in Basel showed that the energy consumption of residential buildings and the construction age had a nonlinear correlation [28]. Brounen et al. surveyed 300,000 Dutch families, and the research results showed that the energy consumption of buildings built before the 1980s is almost 50\% higher [29]. The implementation of "Three Steps Energy Saving" in Beijing City, which is the mandatory standards for building energy-saving heating energy consumption in three stages, including a residential space heating energy saving of $30 \%, 50 \%, 65 \%$, comparing $1980 \mathrm{~s}$ buildings with the residential buildings constructed from 1991 to 1999, from 2000 to 2004 and after 2005, respectively [30]. Further, the residential building classification factor also includes building function, floor area and building shape [4,31,32]. Xiaochen Liu et al. researched family energy consumption and carbon dioxide emissions in the Greater Dublin area, and the results showed that the smaller residential areas demand less energy use [33]. The simulation results of BIM software show that the annual energy consumption of different orientations are quite different [10]. Tianren Yang and other scholars, in the study of residential energy consumption in the residential area of Chongming Island, classified urban residential buildings, platoon villas, Banlou and high-rise residential units [34]. It can be seen that building construction, interior residential area, building height, building orientation, building function and building shape greatly affect internal energy consumption, and they are important classifications for building energy consumption research. 
The influencing factors of energy consumption in residential buildings analysed in different research have difference. Some macro-scale research involved energy market, climate, urbanization, income, and so on. Hossein, for example, defined household, building, home appliances, energy market, climate as five determinants of residential energy consumption [35]. YANG Yanfang et al. showed that urbanization is the most important factor affecting Beijing's building carbon emissions [36]. However, some of these factors are not significant in micro-scale studies. Instead, demographic characteristics, building conditions, lifestyle, household appliances and energy-saving concept are five main influencing items. PU Qingping selected 29 variables out of these items in his research, and the result showed that permanent resident, per capita building area, building type, number of air conditioning and computer, and air conditioning cooling method are the most important factors [37]. The variables analysed in this research came from survey questionnaire data, and 19 of them were selected from the items of household income, household conditions, building conditions, lifestyle, household appliances and energy-saving concept referencing to PU's selection.

Beijing has become China's second largest energy consuming city and entered the stage of building a low-carbon city. The next 20 to 30 years will be the crucial period for the construction of low-carbon city [38].To face the challenge, energy-saving residential buildings renovation gradually began from 2006 [39]. Beijing put forward the comprehensive transformation of the old district built before 1990 [40] and further promoted energy-saving renovation plan [41] during the 12th Five-Year and 13th Five-Year, respectively. However, the energy-saving design and transformation of residential buildings lacks scientific research support.

Based on the above requirements, residential buildings which covered different construction ages and architecture forms in the Olympic Central Area in Beijing (Figure 1) were chosen to simulate residential building energy consumption and analysis influencing factors. This study surveyed a large number of households in 6 existing districts. Subjected to objective conditions, the actual electricity and natural gas energy consumption data cannot be obtained through the energy supply sector. Thus, the results cannot be calibrated. However, we used the real-time meteorological observation date in the case area and the actual energy consumption schedule of the residents to improve the accuracy of the eQUEST software (James J. Hirsch \& Associates, Camarillo, CA, USA), and converted the final energy consumption into standard coal. We comparative analyze the energy consumption intensity of per unit area in different residential building types and explore the social behaviour influencing mechanism behind the energy consumption change, to provide practical reference for energy saving reconstruction of residential buildings in Beijing.

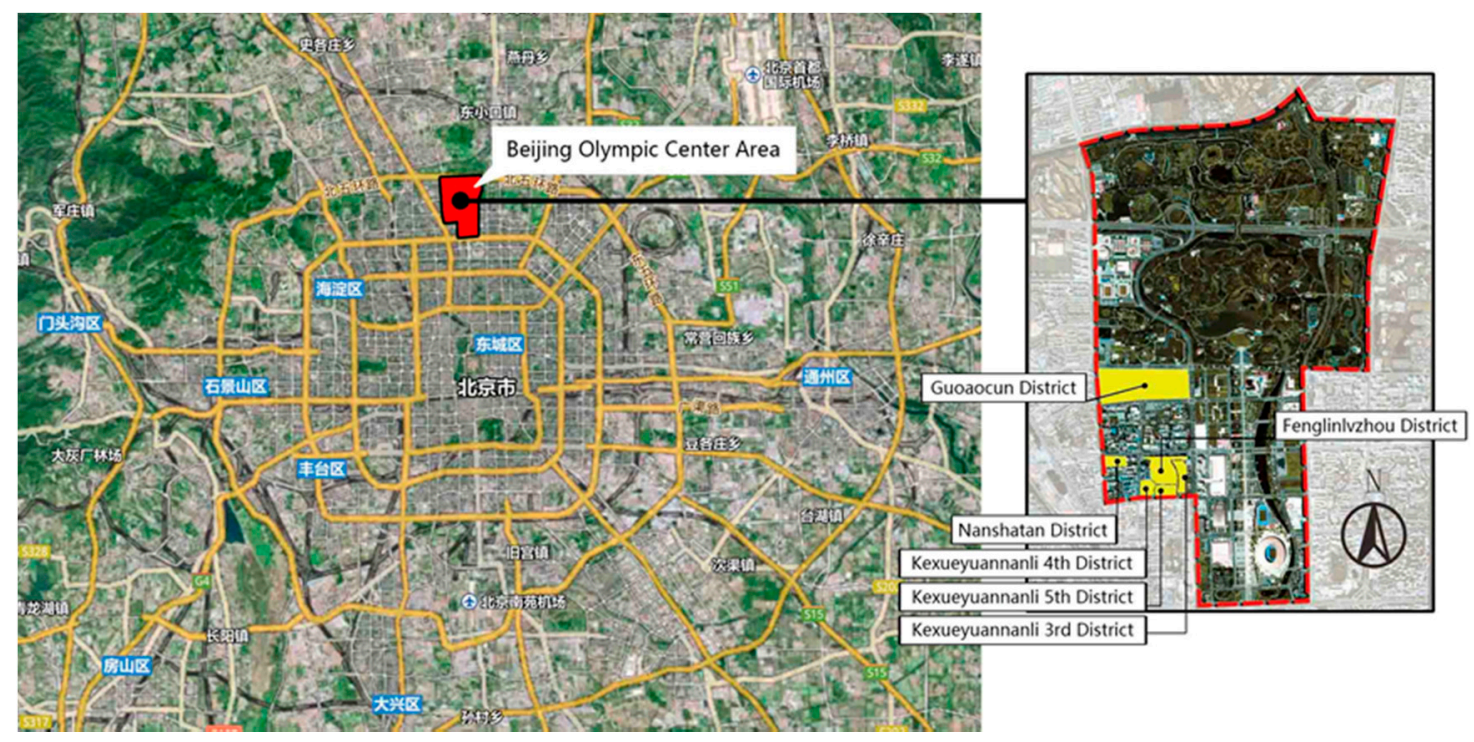

Figure 1. The location of the Beijing Olympic Centre Area and Six Surveyed Districts. 


\section{Data and Methods}

\subsection{Source of Data}

The eQUEST simulation data include meteorological data, building physical structure data, appliance and usage data, and HVAC system data. To ensure the accuracy of the simulation, the Datun Road area real-time meteorological data that are observed by Institute of Geographic Sciences and natural resources research are used instead of the alternative Beijing city standard climate data file downloaded from the EnergyPlus website. The residential buildings' external contour shape data and exterior window wall ratio data are, respectively, obtained by using the AIKE laser rangefinder measurement, an interpretation of the July 2013 Olympic Centre District remote sensing image data, and an interpretation of the residential building facade photo. Due to the difficulty of building construction data, it was referenced from the corresponding national construction standards. The reference specifications include Exterior Insulation Engineering (JGJ144-2004); Energy-saving Building Construction (06J123); the Code for Acceptance of Construction Quality of Building Energy Saving Project (GB40411-2007); and Exterior Insulation Construction (10J121). The appliance usage data in residential buildings and HVAC system data come from a household survey.

\subsection{Building Classification Method}

According to the construction of the "Three Steps Energy Saving" plan in Beijing [30], the residential area is divided into periods, including the 1980s, the 1990s, the period from 2000 to 2004 , and post-2005 construction types. The external walls of the 1980s and 1990s residential buildings in the study area have not been transformed, so they objectively reflect their characteristics. In addition, the four types of construction include building height, architectural structure, architectural forms and the construction of the interior and other differences.

\subsection{Model Refinement}

\subsubsection{Real-Time Meteorological Data Conversion}

The hourly real-time meteorological data for the eQUEST model simulation includes dry bulb temperature, relative humidity, horizontal radiation, wind speed, and wind direction. They are converted by eQUEST Weather Format Convertor.

\subsubsection{Actual Energy Consumption Behaviour Schedule}

Based on the field survey data, we made an actual energy consumption behaviour schedule for HVAC systems, cooking, household appliances, lighting, domestic hot water and in-home rate. We use 1 to stand for the appearance of a certain energy use activity, and we use 0 to stand for no certain energy use activity.

\subsection{Simulation and Calculation}

\subsection{1. eQUEST Modelling}

We built an eQUEST model, which did not include the residential building elevator energy part. The meteorological data, building physical structure data, appliances and usage data, HVAC system data were put into the eQUEST model to obtain the simulation results.

\subsubsection{Elevator Energy Consumption Calculation}

Based on the Technical Conditions of Elevator GB/T 10058-2009 Appendix A (this method is derived from the ISO/DIS25745-1:2008 standard [42]), which can be used to predict the energy 
consumption of elevator operation, the results can be used for an energy consumption assessment of the entire building. The calculation method is shown in Formula (1).

$$
E_{\text {elevstor }}=\left(K_{1} \times K_{2} \times K_{3} \times H \times F \times P\right) /(V \times 3600)+E_{\text {standby }}
$$

$E_{\text {elevstor }}$ refers to the elevator energy consumption within a year $(\mathrm{kWh} / \mathrm{a}) ; K_{1}$ stands for drive system coefficient, the value of which is $1.0 ; K_{2}$ refers to the average running distance coefficient; $K_{3}$ refers to the average load factor, the value of which is $0.35 ; H$ refers to the maximum operating distance (m); $F$ refers to the number of starts in a year, the value of which is generally between $100,000-300,000$; $P$ is the rated power of the elevator, the unit for which is $\mathrm{kW} ; V$ is the elevator speed, the unit for which is $\mathrm{m} / \mathrm{s}$; and $E_{\text {standby }}$ refers to the total energy consumption in a year, the unit for which is $\mathrm{kWh} / \mathrm{a}$.

The power rate of Formula (1) can be calculated as follows:

$$
\begin{gathered}
P=P_{1} \times P_{0} \\
P_{0}=\left(0.5 \times M \times V \times g_{n}\right) /\left(1000 \times n_{s} \times n_{g} \times n_{n} \times n_{m}\right)
\end{gathered}
$$

$M$ is the rated load; $V$ stands for rated speed; $P_{1}$ is the coefficient that is correlated with the equilibrium coefficient, the value of which is $1.0 ; n_{S}$ stands for suspension efficiency, the value of which is $0.85 ; n_{m}$ stands for the transmission efficiency, the value of which is $0.75 ; n_{g}$ stands for the fact that there is no gear transmission coefficient, the value of which is $1 ; n_{n}$ stands for motor efficiency, the value of which is 0.85 ; and $g_{n}$ stands for standard gravity; the value of which is $9.81 \mathrm{~m} / \mathrm{s}^{2}$.

The number of starts in a year $F$ can be calculated according to Formula (4)

$$
F=T \times V \times 365 \times 3600 / H
$$

$T$ is the average running time, which, in the actual calculation is $h /$ day, according to the use of the characteristics of the building to determine the elevator running time and standby time, to determine the $F$ and $E_{\text {standby }}$.

\subsubsection{The Standard Coal Conversion}

According to the 2010 Chinese Energy Statistics Yearbook of all types of energy that are converted to a standard coal reference coefficient table, the power conversion coefficient is $0.12 \mathrm{kgce} / \mathrm{kWh}$, and the coal conversion coefficient of natural gas is $1.33 \mathrm{kgce} / \mathrm{m}$. The energy consumption of the whole building standard coal can be divided into two parts: power and natural gas standard energy consumption, as is shown in Formula (6). Among them, the standard coal consumption of electricity and natural gas is calculated by multiplying the power consumption and the natural gas consumption and the corresponding standard coal conversion coefficient, as is shown in Formulas (7) and (8). Because the combustion of 1 cubic feet of natural gas produces 1031 Btu heat, $1 \mathrm{ft}^{3}=0.03 \mathrm{~m}^{3}$, Formula (9) shows the calculation of consumed nature gas volume $V_{\text {ngas }}$. The annual energy consumption per unit area of residential buildings in the study area is calculated by the quotient of the sum of the different types of residential buildings' energy consumption and the total area of the residential buildings, as Formula (5) shows.

$$
\begin{gathered}
\bar{E}=\frac{\sum_{i=1}^{n} E_{i} \times A_{i}}{\sum_{i=1}^{n} A_{i}} \\
E_{i}=E_{i, \text { electricity }}+E_{i, n g a s} \\
E_{i, \text { electricity }}=Q_{\text {electricity }} \times \eta_{\text {electricity }} \\
E_{i, n g a s}=V_{\text {ngas }} \times \eta_{n g a s} \\
V_{\text {ngas }}=\frac{Q_{n g a s, B t u} \times 0.02831685 \mathrm{~m}^{3} / \mathrm{ft}^{3}}{1031 \mathrm{Btu} / \mathrm{ft}^{3}}
\end{gathered}
$$


$\bar{E}$ is the case of the average energy consumption of unit building area, $A_{i}$ is the total construction area of building $i$; $E_{i}$ is the total standard coal energy consumption of building $i$; $E_{i, \text { electricity }}$ is the standard coal power consumption of building $i ; E_{i, n g a s}$ is the standard coal nature gas consumption of building $i$; $\eta_{\text {electricity }}$ is the power that is converted to a standard coal coefficient; and $\eta_{n g a s}$ is the natural gas that is converted to a standard coal coefficient.

\section{Results}

\subsection{Questionnaires}

The research surveyed 600 samples, approximately $5 \%$ of 10,864 households from 154 residential buildings in the central area of the 6 Olympic residential districts. The questionnaires were reasonably allocated according to the amount of the buildings and the households, as well as the different floors. We hired a qualified professional survey company, with our research experts, to organize two times field surveys. The first time is from 13 July 2016 to 31 August 2016, and the second time is in December 2016. Finally, we filtered 572 valid questionnaires: 59 from the Guoaocun District, 101 from the Fenglinlvzhou District, 230 from the Nanshatan District; 63 from the Kexueyuannanli 3rd District, 63 from the Kexueyuannanli 4th District, and 63 from the Kexueyuannanli 5th District.

\subsection{Building Classification and Typical Building Selection}

Fenglinlvzhou District residential buildings (built in the period from 2000 to 2004) include towers and slab-type apartment buildings. Some of the tower's planes are larger than others, so the Fenglinlvzhou District is divided into three types of simulation. The Nanshatan District (built in the period of 1980s) is divided into high-rise towers and multi-storey slab-types. Kexueyuannanli's residential buildings (built in the period of 1990s) are divided into mid-sized apartment buildings and small-sized apartment buildings (see Figure 2). The final case area is divided into 8 categories (see Table 1), and a typical residential building is selected for simulation and analysis (see Figure 3). From the basic information of 8 categories, we can see that reinforced concrete structures and high-rise buildings and buildings with elevators are mostly concentrated in constructions after 2000.

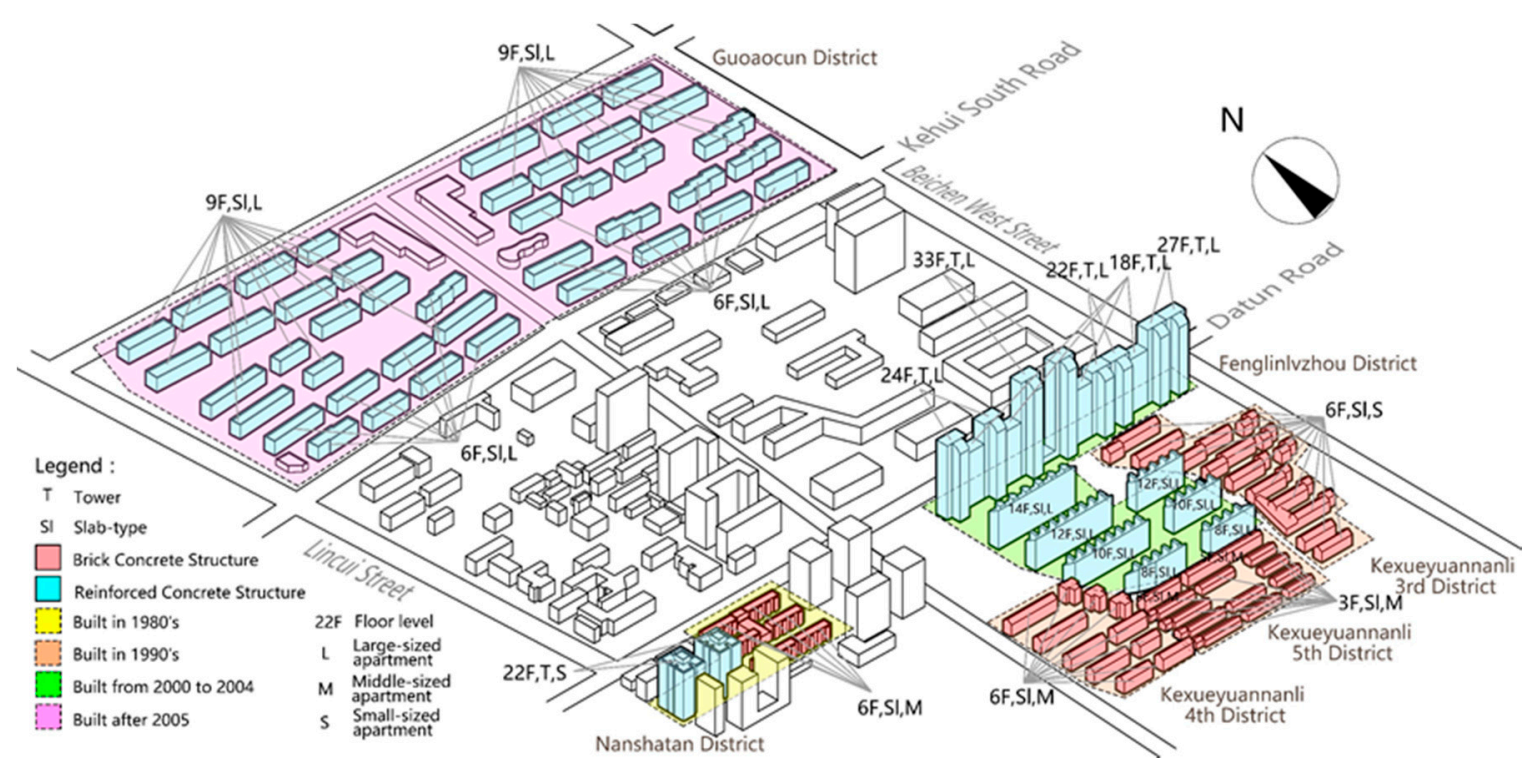

Figure 2. Residential building classification in study area. 
Table 1. Basic information of 8 selected typical buildings.

\begin{tabular}{|c|c|c|c|c|c|c|c|c|}
\hline Type & 1 & 2 & 3 & 4 & 5 & 6 & 7 & 8 \\
\hline construction form & $\mathrm{T}$ & SL & SL & SL & $\mathrm{T}$ & $\mathrm{T}$ & SL & SL \\
\hline floor level & 22 & 6 & 6 & 6 & 33 & 18 & 10 & 6 \\
\hline elevator & $\sqrt{ }$ & - & - & - & $\sqrt{ }$ & $\sqrt{ }$ & $\sqrt{ }$ & $\sqrt{ }$ \\
\hline apartment size & S & $\mathrm{M}$ & $\mathrm{S}$ & M & $\mathrm{L}$ & $\mathrm{L}$ & $\mathrm{L}$ & $\mathrm{L}$ \\
\hline space heating & $\mathrm{DH} / \mathrm{NG}$ & $\mathrm{DH} / \mathrm{NG}$ & $\mathrm{DH} / \mathrm{NG}$ & $\mathrm{DH} / \mathrm{NG}$ & $\mathrm{DH} / \mathrm{NG}$ & $\mathrm{DH} / \mathrm{NG}$ & $\mathrm{DH} / \mathrm{NG}$ & WSHP \\
\hline space cooling & DCS & DCS & DCS & DCS & DCS & DCS & DCS & WSHP \\
\hline Domestic hot water & NG & NG & NG & NG & NG & NG & NG & NG \\
\hline
\end{tabular}

Notes: T stands for tower building; SL stands for slab-type building; RC stands for reinforced concrete structure; BC stands for brick-concrete structure; S stands for small-sized apartment; $\mathrm{M}$ stands for mid-sized apartment; L stands for large-sized apartment; DH stands for district heating; NG stands for nature gas; DCS stands for decentralized air conditioning; WSHP stands for water source heat pump.

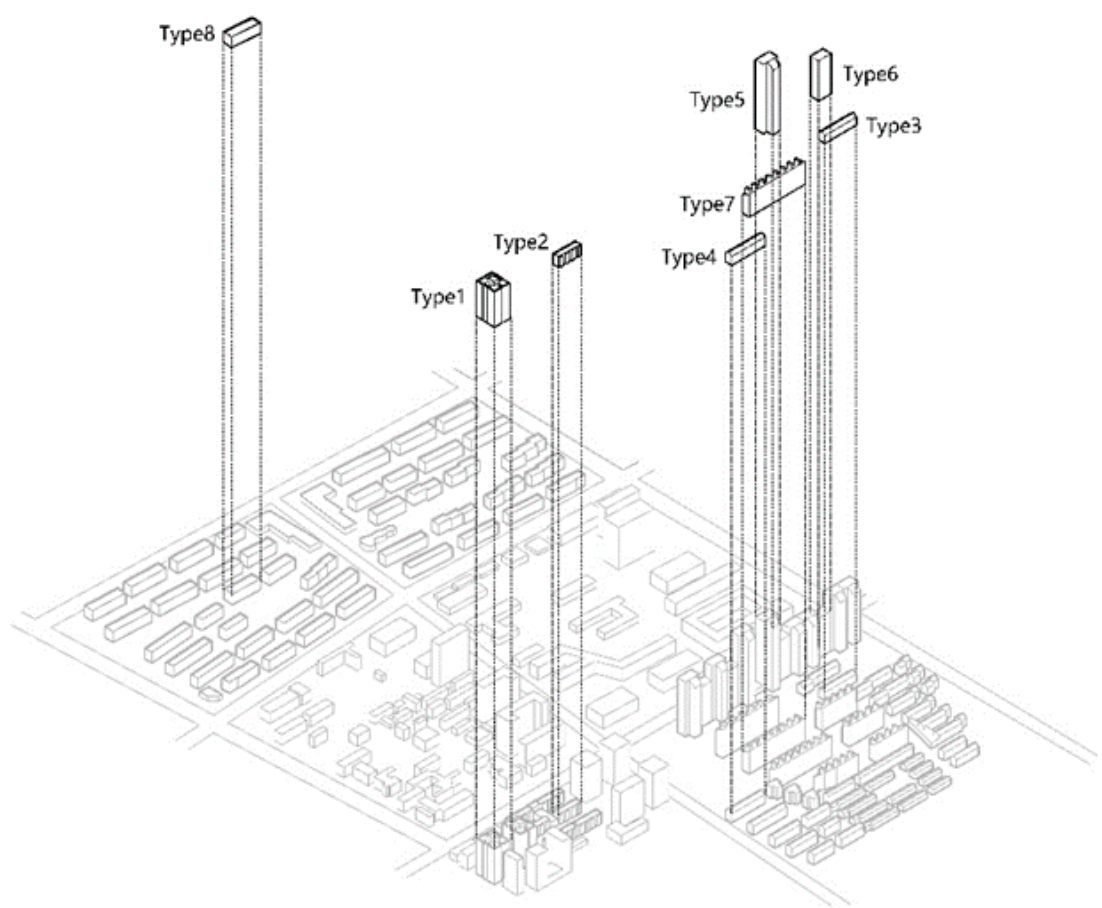

Figure 3. Typical building selection in study area.

\subsection{Real-Time Meteorological File}

By using the eQUEST Weather Format Convertor (James J. Hirsch \& Associates, Camarillo, CA, USA), these five types of meteorological data from the Olympic Centre in 2015 were converted from CSV format files into bin format files. They were then imported into the eQUEST simulation model (Figure 4). 


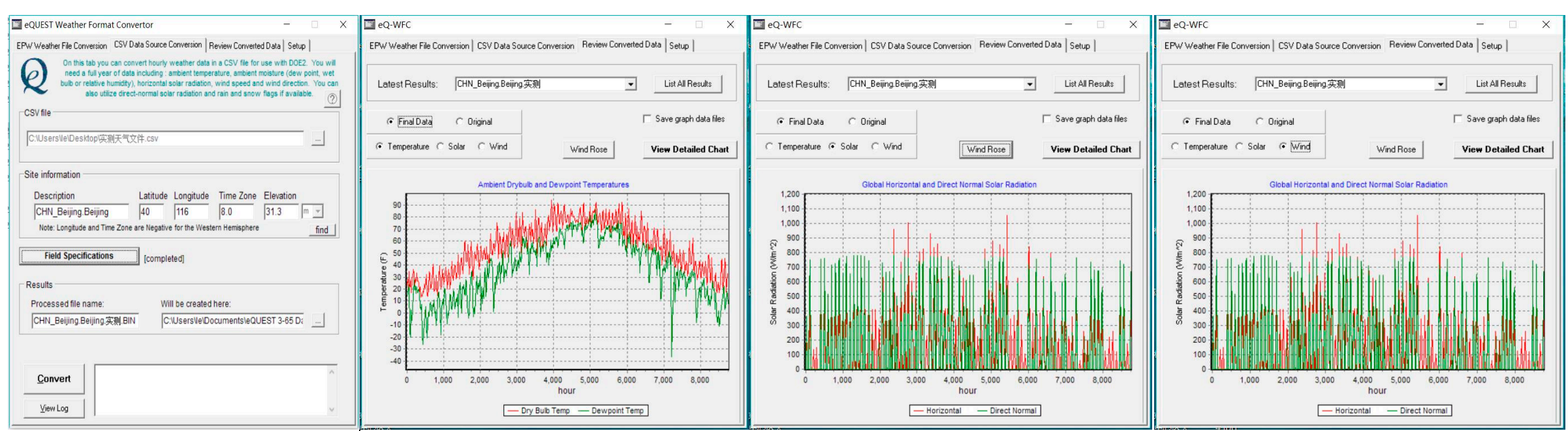

Figure 4. eQUEST Weather Convertor, Format Convertor software and converted real-time meteorological data. 


\subsection{Actual Energy Consumption Behaviour Schedule}

We statistical calculated 6 energy usage scenarios for 8 types of residential buildings. Figure 5 showed the 6 energy usage scenarios for type 4 residential building. The cooking, appliances usage, daily lighting, cooling and hot water supply of type 4 residential buildings was represented by a frequency curve of $24 \mathrm{~h}$, respectively, and the daily in home rate was represented by a frequency curve of one year.

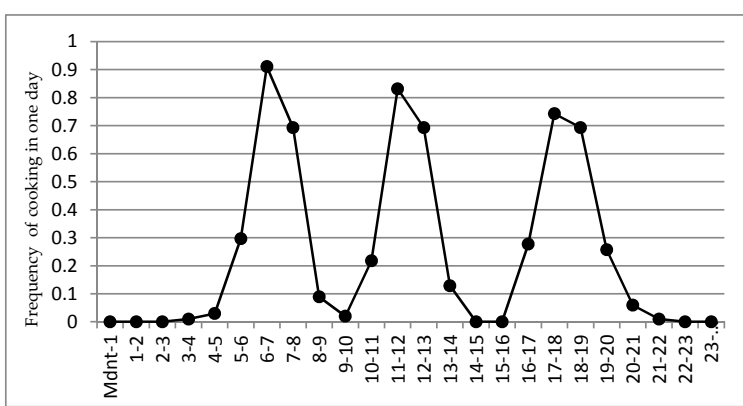

(a)

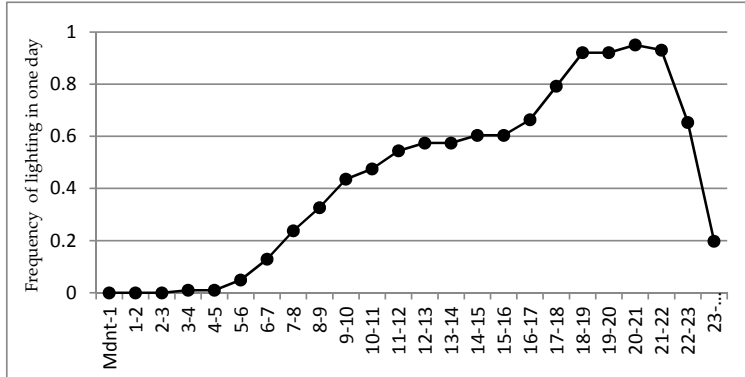

(c)

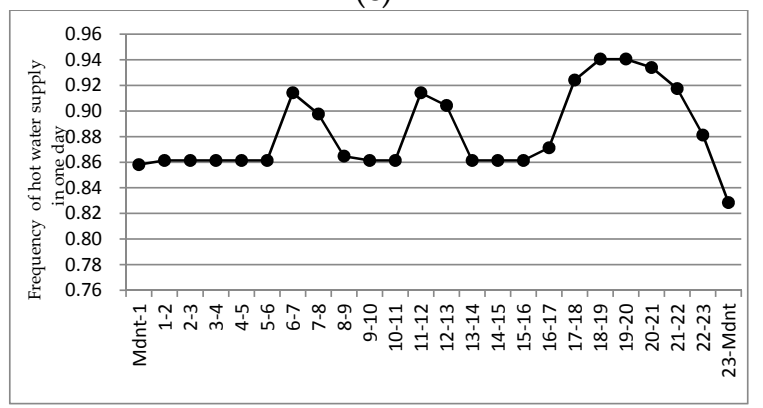

(e)

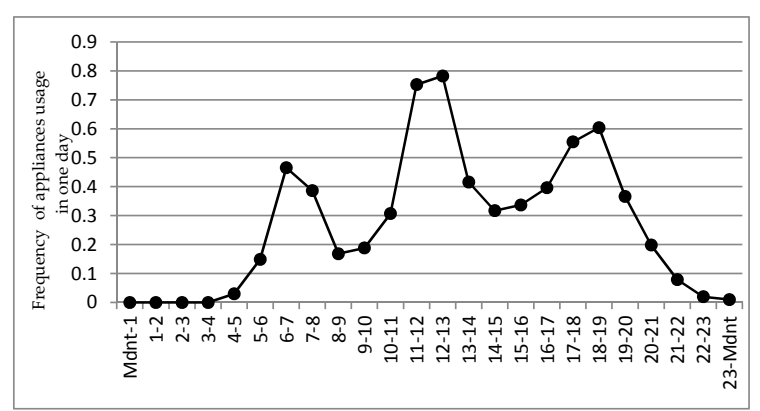

(b)

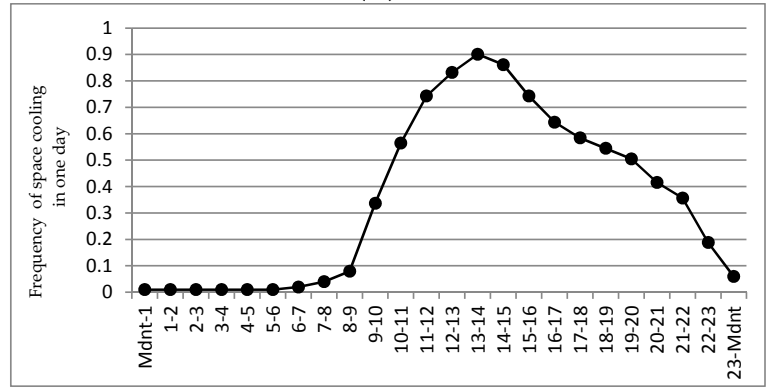

(d)

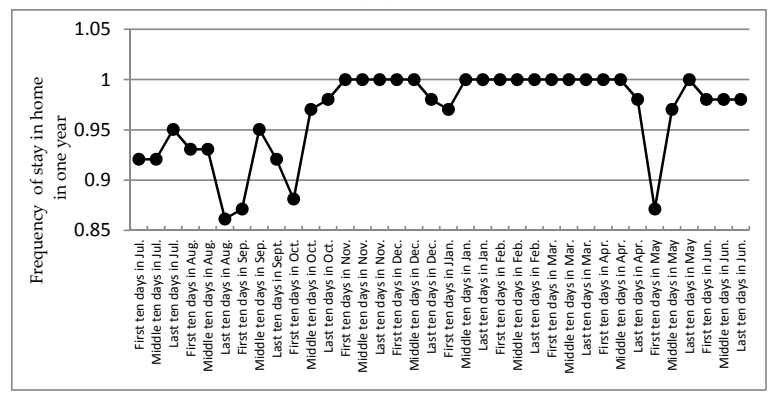

(f)

Figure 5. Actual Energy Consumption Behaviour Schedules. Notes: (a) is the cooking schedule of type 4 building; (b) is the appliances usage schedule of type 4 building; (c) is the daily lighting schedule of type 1 building; (d) is the daily space cooling schedule of type 4 building; (e) is the daily domestic hot water supply schedule of type 4 building; (f) is the daily in home rate schedule of type 4 building.

\section{5. eQUEST Models}

The eQUEST simulation model for the construction of the 8 typical residential buildings are carried out (see Figure 6). 


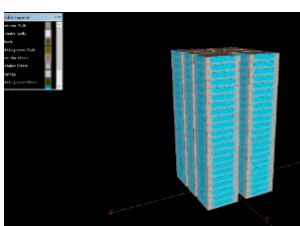

(a)

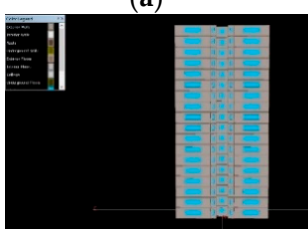

(e)

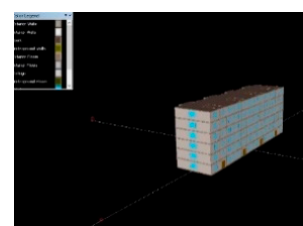

(b)

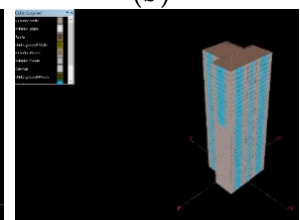

(f)

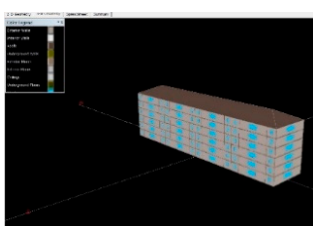

(c)

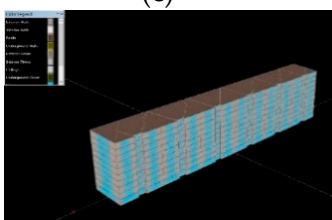

(g)

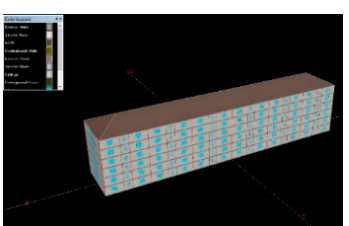

(d)

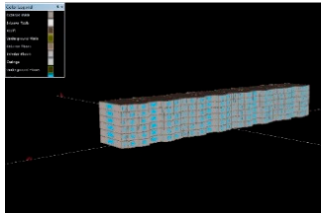

(h)

Figure 6. Models of 8 typical residential buildings. Notes: $(\mathbf{a}-\mathbf{h})$, respectively, show the model of type 1 building to type 8 building.

\subsection{Standard Coal Conversion Result}

Through eQUEST simulation and energy consumption calculation, the energy consumption of each type of residential construction unit is obtained. Among them, the energy consumption of type 1 to type 8 were $24.39 \mathrm{kgce} /\left(\mathrm{m}^{2} \cdot \mathrm{a}\right), 36.58 \mathrm{kgce} /\left(\mathrm{m}^{2} \cdot \mathrm{a}\right), 29.76 \mathrm{kgce} /\left(\mathrm{m}^{2} \cdot \mathrm{a}\right), 30.37 \mathrm{kgce} /\left(\mathrm{m}^{2} \cdot \mathrm{a}\right)$, $25.52 \mathrm{kgce} /\left(\mathrm{m}^{2} \cdot \mathrm{a}\right), 25.57 \mathrm{kgce} /\left(\mathrm{m}^{2} \cdot \mathrm{a}\right), 33.25 \mathrm{kgce} /\left(\mathrm{m}^{2} \cdot \mathrm{a}\right)$, and $9.34 \mathrm{kgce} /\left(\mathrm{m}^{2} \cdot \mathrm{a}\right)$. The total energy consumption of residential buildings in the case area in 2015 is 21,262.28 tce, and the average energy consumption per unit area is $20.09 \mathrm{kgce} /\left(\mathrm{m}^{2} \cdot \mathrm{a}\right)$. Separate from the winter heating part, the rest of the consumption per unit area is $11.17 \mathrm{kgce} /\left(\mathrm{m}^{2} \cdot \mathrm{a}\right)$, which is below the Beijing average energy consumption level of $19 \mathrm{kgce} /\left(\mathrm{m}^{2} \cdot \mathrm{a}\right)$, based upon research by the Energy Conservation and Research Centre of Tsinghua University in Beijing in 2009. The monthly energy consumption results are shown in Figure 7.

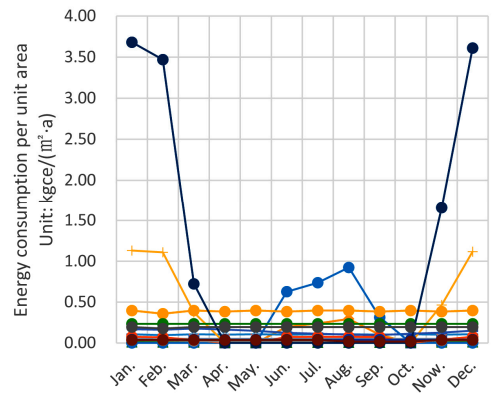

(a)

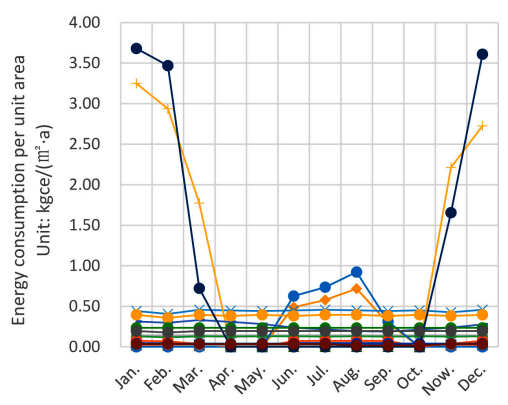

(c)

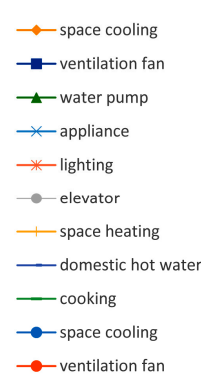

$\rightarrow$ ventilation fan

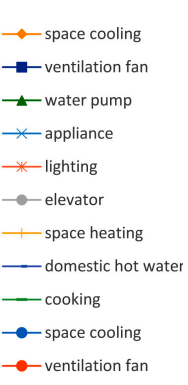

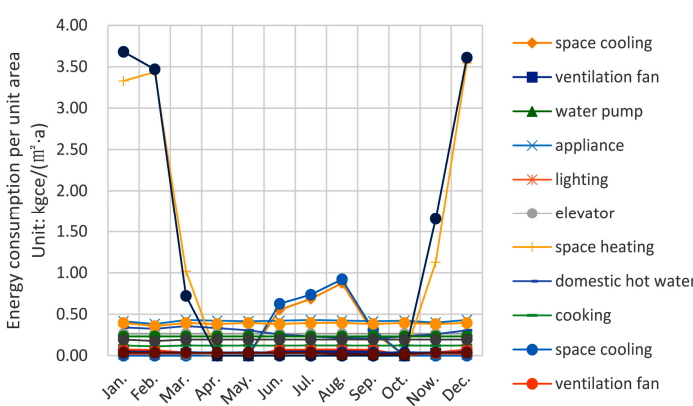

(b)

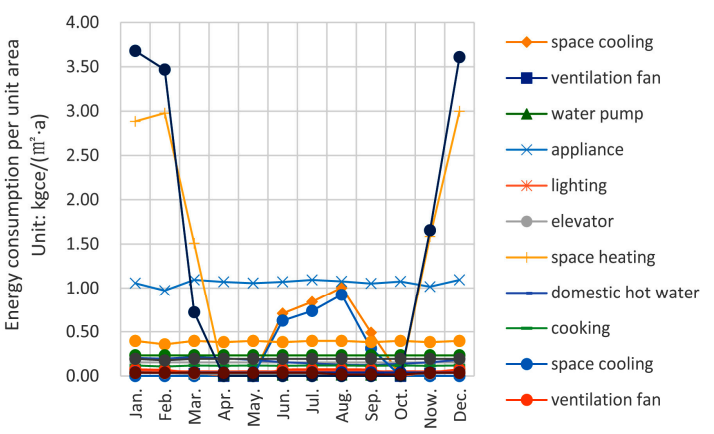

(d)

Figure 7. Cont. 


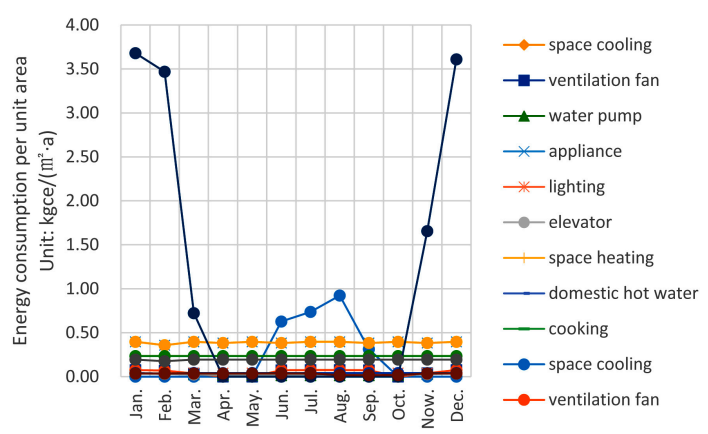

(e)

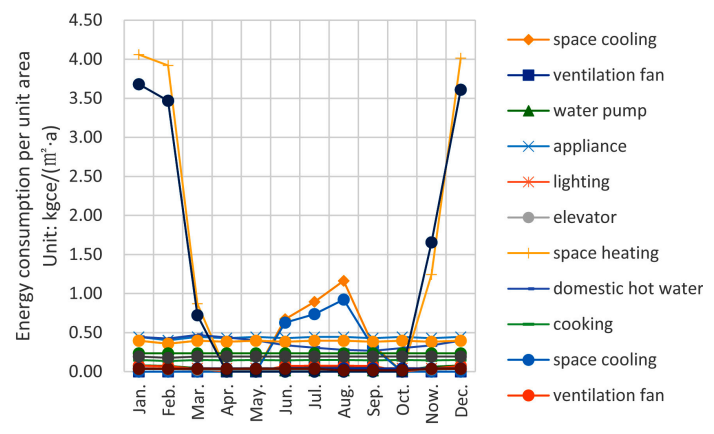

(g)

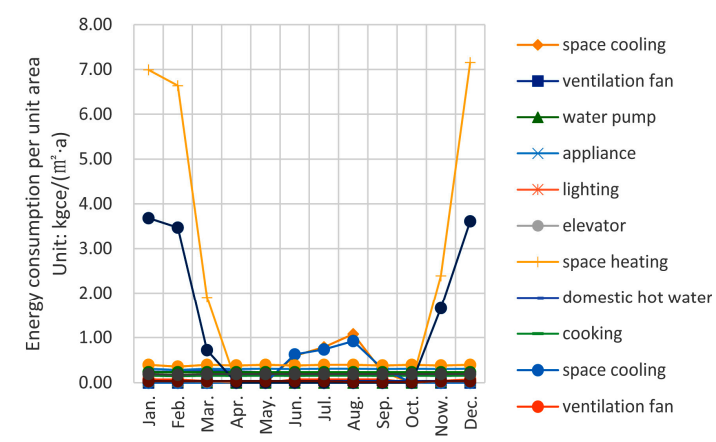

(f)

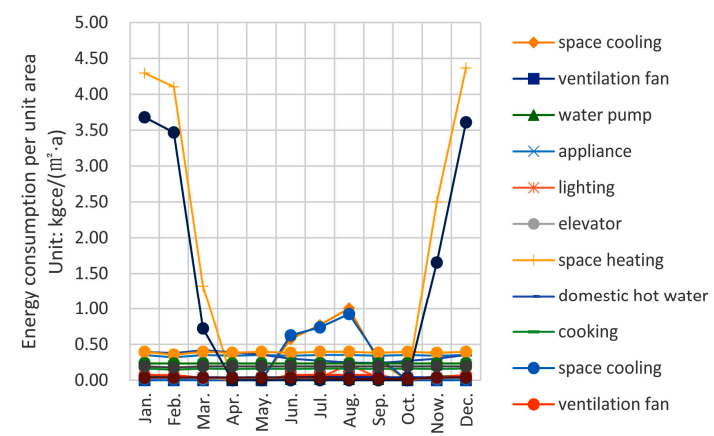

(h)

Figure 7. The simulation results of 8 typical residential buildings. Notes: $(\mathbf{a}-\mathbf{h})$, respectively, show the model of type 1 building to type 8 building.

\section{Discussion}

\subsection{Composition and Variance Analysis of Total Energy Consumption}

Of the overall energy consumption structure, space heating represents the greatest annual energy consumption per unit area, with a proportion of $45 \%$. Appliance energy consumption is second, with a proportion of $20 \%$; domestic hot water energy consumption is third, with $11 \%$; space cooling energy consumption is fourth, with $9 \%$; and elevator and cooking are 5\%, respectively. In apartment buildings with elevators, the unit area of residential building elevator energy consumption accounted for $7 \%$ of the total energy consumption. Visible elevator energy consumption in residential buildings represents a certain proportion of energy consumption (see Table 2).

Table 2. Annual energy consumption composition of case area and buildings with elevators.

\begin{tabular}{ccccc}
\hline \multirow{2}{*}{$\begin{array}{c}\text { Type of Energy } \\
\text { Consumption }\end{array}$} & \multicolumn{2}{c}{ Buildings of Case Area } & \multicolumn{2}{c}{ Buildings with Elevators } \\
\cline { 2 - 5 } & $\begin{array}{c}\text { Annual Energy } \\
\text { Consumption/kgce }\end{array}$ & Proportion/\% & $\begin{array}{c}\text { Annual Energy } \\
\text { Consumption/kgce }\end{array}$ & Proportion/\% \\
\hline Space cooling & $1,851,379$ & 9 & $1,341,474$ & 8 \\
Ventilation fan & 393,530 & 2 & $354,078.9$ & 2 \\
Water pump & $186,186.2$ & 1 & $117,400.8$ & 1 \\
Appliance & $4,227,628$ & 20 & $3,395,449$ & 21 \\
Lighting & $505,866.7$ & 2 & $413,266.5$ & 2 \\
Elevator & $\mathbf{1 , 0 6 9 , 8 9 5}$ & $\mathbf{5}$ & $\mathbf{1 , 0 6 9 , 8 9 5}$ & 7 \\
Space heating & $9,782,272$ & 46 & $7,001,752$ & 43 \\
Domestic hot water & $2,491,761$ & 12 & $1,783,222$ & 11 \\
Cooking & $1,093,551$ & 5 & $774,240.3$ & 5 \\
Total & $21,262,282$ & 100 & $16,250,779$ & 100 \\
\hline
\end{tabular}

We identified 8 types of residential building energy use, including space heating, space cooling, fan, water pump, appliances, lighting, domestic hot water, and cooking. We obtained the annual total 
energy consumption using an SPSS analysis of variance, and we analysed the differences between the groups (see Table 3). Because the space heating and cooling consumption is extremely different among the seasons, the influence of a non-cooling season and a non-heating season is eliminated in the two analyses. In this analysis, elevator energy consumption is determined in accordance with the "elevator technical conditions" GB/T 10058-2009 Appendix A calculation, and not the simulation value. The results showed that there was no significant difference in space cooling consumption between the groups, and there were differences in fan energy consumption among the groups. In general, building type has a great impact on the final energy consumption.

Table 3. Analysis of Variance.

\begin{tabular}{cccccccccc}
\hline & $\begin{array}{c}\text { Space } \\
\text { Heating }\end{array}$ & $\begin{array}{c}\text { Space } \\
\text { Cooling }\end{array}$ & $\begin{array}{c}\text { Ventilation } \\
\text { Fan }\end{array}$ & Pump & Appliance Lighting & $\begin{array}{c}\text { Domestic } \\
\text { Hot Water }\end{array}$ & Cooking & $\begin{array}{c}\text { Total Energy } \\
\text { Consumption }\end{array}$ \\
\hline SSA & 55.880 & 0.723 & 0.010 & 0.090 & 6.356 & 0.023 & 1.002 & 0.192 & 12.944 \\
SSE & 0.378 & 4.178 & 0.057 & 0.020 & 0.024 & 0.033 & 0.195 & 0.001 & 37.443 \\
sig. & 0.000 & 0.600 & 0.043 & 0.000 & 0.000 & 0.000 & 0.000 & 0.000 & 0.000 \\
\hline
\end{tabular}

\subsection{Comparison of Energy Consumption in Different Types of Buildings}

In this part, we comparative analyzed the energy consumption in different types of buildings, according to construction age, building height, apartment sizes, and construction forms. The type 8 (Guoaocun District, built after 2005) applied the water source heat pump system, which reduced space heating and space cooling energy consumption much more than the natural gas district heating system, will affect the results of the comparative analysis. Therefore, in the comparative analysis for energy consumption per unit area according to building height, apartment sizes, and construction forms, we exclude the type 8 , and only analyzed the other 7 types residential buildings, which applied the natural gas district heating system.

\subsubsection{Comparison of Energy Consumption of Residential Buildings in Different Ages}

Generally, the difference in energy consumption per unit area of residential buildings during different construction time periods is large, and the energy consumption per unit area decreases over time. The buildings that were constructed after 2005 have a minimum energy consumption per unit of $9.34 \mathrm{kgce} /\left(\mathrm{m}^{2} \cdot \mathrm{a}\right)$, and the 1980s buildings have a maximum energy consumption per unit of $30.52 \mathrm{kgce} /\left(\mathrm{m}^{2} \cdot \mathrm{a}\right)$. The 1980s and 1990s building heating unit area energy consumption was $25.07 \mathrm{kgce} /\left(\mathrm{m}^{2} \cdot \mathrm{a}\right)$ and $14.92 \mathrm{kgce} /\left(\mathrm{m}^{2} \cdot \mathrm{a}\right)$, which is higher than the average value of Beijing city civil building heating energy consumption in 2014 , at $13.9 \mathrm{kgce} /\left(\mathrm{m}^{2} \cdot \mathrm{a}\right)$ [43]. Buildings that were built in the 1990s, the period from 2000 through 2004, and after 2005 have heating energy savings of $14.1 \%, 26.2 \%$, $76 \%$, respectively, compared to the heating energy consumption of buildings that were built in the 1980s. The building energy consumption is greatly reduced in the buildings that were built after 2000, which is related to the upgrading of the building structure and the change of heating form. The hot water energy minimum was in the 1980 s buildings, at $1.13 \mathrm{kgce} /\left(\mathrm{m}^{2} \cdot \mathrm{a}\right)$, followed by the 2000 building, at $2.49 \mathrm{kgce} /\left(\mathrm{m}^{2} \cdot \mathrm{a}\right)$, and the highest were the buildings that were built in the $1990 \mathrm{~s}$, at $4.24 \mathrm{kgce} /\left(\mathrm{m}^{2} \cdot \mathrm{a}\right)$. In addition, the unit area of space cooling and cooking consumption is influenced by the age of the building. The 1980s and 1990s building exterior wall insulation performance is poor, and the space cooling energy consumption is higher than the 2000-2004 buildings, and the buildings that were built after 2005 had lower space cooling energy consumption due to the use of water source heat pump centralized space cooling. Cooking gas is more affected by user behaviour.

\subsubsection{Comparison of Energy Consumption of Residential Buildings with Different Heights}

The residential buildings in the study area are divided into two types according to the height of the buildings. They are high-rise buildings (more than 10 floors) and multi-storey buildings (between 3 and 6 floors). These structures appear to correspond to the reinforced concrete structure and the brick 
and concrete structure buildings in Figure 8. The overall energy consumption differences between the two types of building is small, at only $1.27 \mathrm{kgce} /\left(\mathrm{m}^{2} \cdot \mathrm{a}\right)$. The total energy consumption per unit area of the high-rise buildings was lower than the energy consumption in multi-story buildings by $4 \%$. High-rise buildings showed good structural insulation performance because they are $22 \%$ more energy efficient in space heating, $16 \%$ more efficient in space cooling, and 37\% more efficient in domestic hot water energy consumption compared with multi-storey buildings. However, high-rise buildings per unit area of household appliance energy consumption is $7.26 \mathrm{kgce} /\left(\mathrm{m}^{2} \cdot \mathrm{a}\right)$, which is $53 \%$ higher than that in multi-storey buildings. Elevator energy consumption accounted for $7 \%$ of high-rise buildings per unit area of energy consumption. To reduce such energy consumption, the high-rise building relative to the multi-storey building energy savings per unit area is $11 \%$.

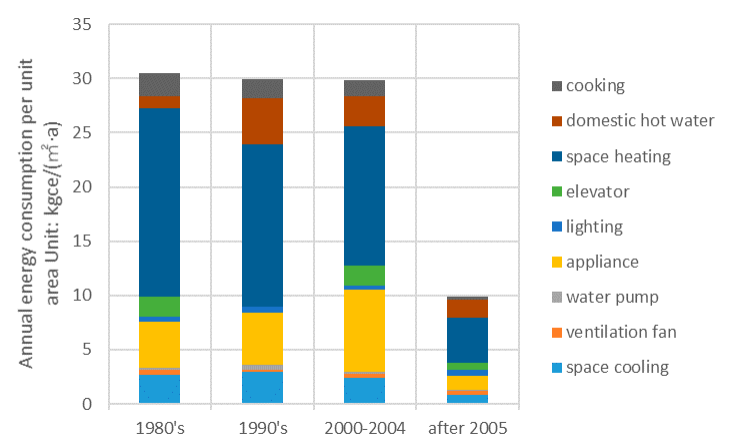

(a)

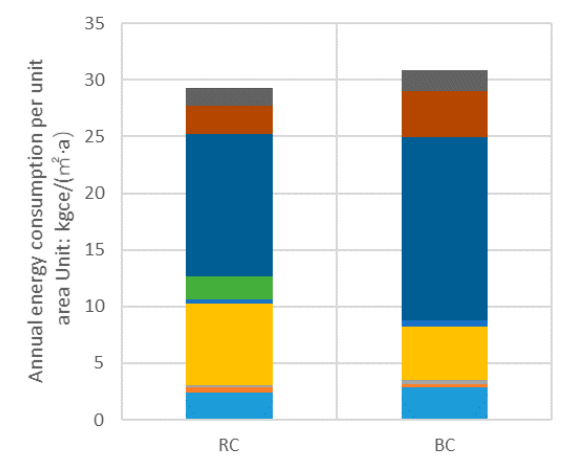

(c)

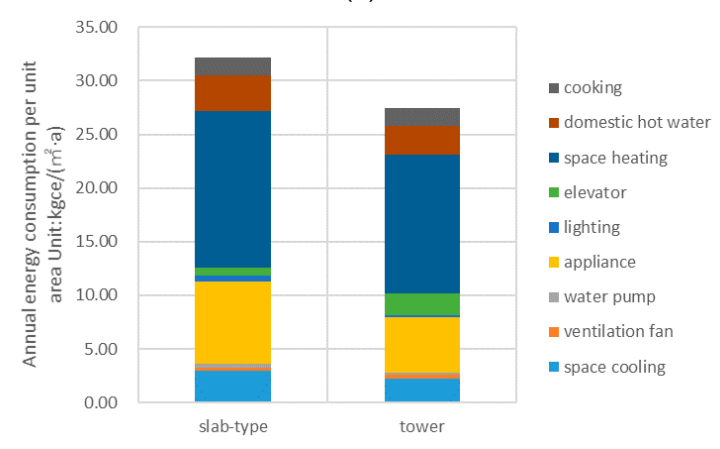

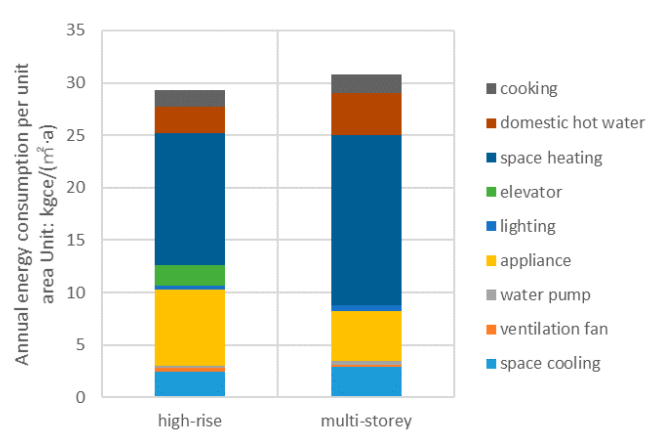

(b)

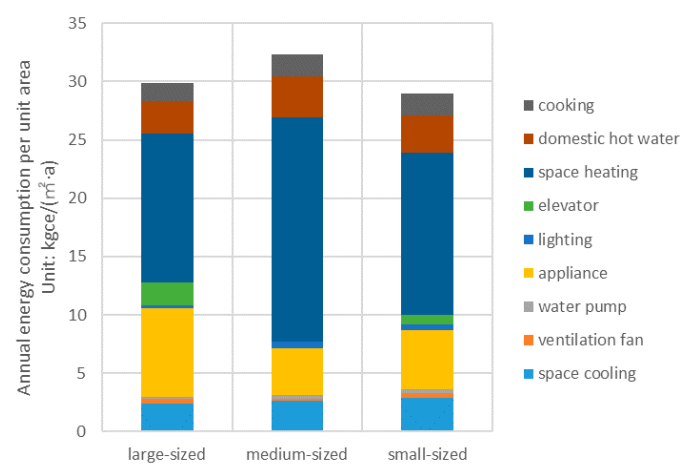

(d)

(e)

Figure 8. Different types of buildings per unit area of different sources of energy consumption comparison (a) Comparison of Energy Consumption of Residential Buildings in Different Ages; (b) Comparison of Energy Consumption of Residential Buildings with Different Heights; (c) Comparison of Energy Consumption of Residential Buildings with Different Building Structures;

(d) Comparison of Energy Consumption of Residential Buildings with Different Apartment sizes; (e) Comparison of Energy Consumption of Residential Buildings with Different Construction Forms. 


\subsubsection{Comparison of Energy Consumption of Residential Buildings with Different Apartment sizes}

According to the building interior units, the residential buildings in the case study area are divided into three types of building: small-sized apartment buildings (apartment area is less than $60 \mathrm{~m}^{2}$ ), medium-sized apartment buildings (apartment area is between 60 and $120 \mathrm{~m}^{2}$ ), and large-sized apartment buildings (apartment area is more than $120 \mathrm{~m}^{2}$ ). Among them, small-sized apartment buildings have the lowest energy consumption per unit area of $29.02 \mathrm{kgce} /\left(\mathrm{m}^{2} \cdot \mathrm{a}\right)$, and medium-sized apartment buildings' energy consumption per area is the highest, at $32.32 \mathrm{kgce} /\left(\mathrm{m}^{2} \cdot \mathrm{a}\right)$. Some of the recent research has shown that small-sized apartments are more energy efficient, and the state has published policy terms to encourage small apartment buildings. However, large-sized buildings in the case study area showed more energy reduction in space cooling $(18 \%)$, space heating $(7 \%)$ and domestic hot water (14\%) than the small-sized buildings. This may be because the large-sized apartment buildings in the case study area were constructed later and have more energy-efficient exterior structures. In addition, there is an average of 0.02 people per unit area in large-sized apartment buildings, whereas the number in small-sized ones is 0.05. Occupants in small-sized apartment buildings are more intensive, so is the energy use. In the Kexueyuannanli District, the buildings were constructed during the same time period, and their external maintenance structures are similar. The small-sized apartment buildings save $2 \%$ of all energy consumption and have a lower space heating energy consumption than the medium-sized apartment buildings at $15 \%$.

\subsubsection{Comparison of Energy Consumption of Residential Buildings with Different Construction Forms}

The residential buildings in the study area are divided into two main types of slab-type building and towers. Overall, the total annual energy consumption per unit area of towers is lower than that of slab-type buildings by $15 \%$. Based on the composition of the energy consumption, towers' annual space cooling, space heating and appliance energy consumption per unit area of energy consumption are $72 \%, 63 \%$ and $69 \%$, respectively, compared to the slab-type buildings. However, towers have abundant orientations, and the number of north- and west-oriented rooms accounted for a relatively large proportion. Therefore, space cooling and heating energy demand more, and energy consumption should be relatively high. In the Fenglinlvzhou District, the space heating energy consumption per unit area in slab-type buildings (type 4) is $11.95 \mathrm{kgce} /\left(\mathrm{m}^{2} \cdot \mathrm{a}\right)$, which is relatively less than that in towers, which is $12.46 \mathrm{kgce} /\left(\mathrm{m}^{2} \cdot \mathrm{a}\right)$ (type 2$)$ and $12.90 \mathrm{kgce} /\left(\mathrm{m}^{2} \cdot \mathrm{a}\right)$ (type 3$)$, respectively.

\subsection{Analysis of Household Energy Impact Variables in Residential Buildings in Case Area}

The impact of energy consumption in residential buildings usually involves household income, household conditions, building conditions, lifestyle, household appliances and energy-saving concept. This study select the per capita income, resident population, construction age, residential floor, and so on, from the six aspects. The correlation of these variables to the energy consumption of households in residential buildings are analyzed. Household energy consumption is calculated by eQUEST energy consumption simulation of all types of residential buildings per unit area (Table 4).

19 selected factors that affect household energy consumption are shown in Table 3. Semi-parametric treatment was made for building height (BH), building structure (BS), architectural form (AF), internal unit (IU) and construction age (CA). For BH, the high-rise building is assigned to 1, multi-storey building assignment 2; for $\mathrm{BC}$, the concrete building is assigned to 1, brick and concrete structure is assigned to 2; for $\mathrm{AF}$, the tower building is assigned to 1 , floor building is assigned to 2 ; for $\mathrm{CA}$, the construction after 2005 is assigned to 1 , the 2000-2004 construction is assigned to 2 , the 1990s construction assignment to 3 , the 1980s construction assignment to 4 ; for IU, the large-sized apartment is assigned to 1 , the medium-sized apartment is assigned to 2, the small-sized apartment is assigned to 3 . 
A stepwise linear regression analysis was performed using SPSS20.0. The final model variables are internal units, building height, per capita building area, the number of residents, length of power use five variables. The $R^{2}$ of the model is 0.949 and the Sig value is 0.000 , which proves that the model has high accuracy and the result of regression is feasible (Table 5).

Table 4. Influencing Variables.

\begin{tabular}{|c|c|c|c|c|}
\hline Item & Variable & Symbol & Variable Declaration & Unit \\
\hline Household income & Per capita income & PCI & $\begin{array}{l}\text { Resident per capita } \\
\text { net income }\end{array}$ & Yuan per capita \\
\hline $\begin{array}{l}\text { Household } \\
\text { condition }\end{array}$ & Number of residents & NR & $\begin{array}{c}\text { Number of } \\
\text { family residents }\end{array}$ & person \\
\hline \multirow{7}{*}{ Building condition } & Building height & $\mathrm{BH}$ & Height of the buildings & Semi-parametric \\
\hline & Building structure & BS & $\begin{array}{l}\text { The structure of } \\
\text { the building }\end{array}$ & Semi-parametric \\
\hline & Architectural form & $\mathrm{AF}$ & The form of the building & Semi-parametric \\
\hline & Internal Unit & $\mathrm{IU}$ & The size of internal unit & Semi-parametric \\
\hline & Construction age & CA & $\begin{array}{l}\text { The construction age of } \\
\text { the building }\end{array}$ & Semi-parametric \\
\hline & Per capita building area & PCA & $\begin{array}{l}\text { Per capita possession of } \\
\text { the building area }\end{array}$ & Square meter \\
\hline & Floor number & $\mathrm{FN}$ & Living floor number & Floor \\
\hline \multirow{5}{*}{ Lifestyle } & $\begin{array}{c}\text { Summer air } \\
\text { conditioning strategy }\end{array}$ & SAC & $\begin{array}{l}\text { Summer air conditioning } \\
\text { daily cooling time }\end{array}$ & Hour \\
\hline & $\begin{array}{l}\text { The number of } \\
\text { weekly cooking }\end{array}$ & NWC & Weekly cooking times & Time \\
\hline & $\begin{array}{l}\text { Hot water supply strategy } \\
\text { in winter }\end{array}$ & HWW & $\begin{array}{l}\text { Hot water daily supply } \\
\text { time in winter }\end{array}$ & Hour \\
\hline & $\begin{array}{l}\text { Hot water supply strategy } \\
\text { in summer }\end{array}$ & HWS & $\begin{array}{l}\text { Hot water daily supply } \\
\text { time in summer }\end{array}$ & Hour \\
\hline & $\begin{array}{l}\text { Hot water supply strategy } \\
\text { in spring and autumn }\end{array}$ & HWSA & $\begin{array}{l}\text { Hot water daily supply } \\
\text { time in spring and autumn }\end{array}$ & Hour \\
\hline \multirow{3}{*}{$\begin{array}{l}\text { Household } \\
\text { appliance }\end{array}$} & $\begin{array}{l}\text { Number of air } \\
\text { conditioners }\end{array}$ & NAC & $\begin{array}{l}\text { Number of air } \\
\text { conditioners }\end{array}$ & Unit \\
\hline & Number of televisions & NT & Number of televisions & Unit \\
\hline & Number of computers & $\mathrm{NC}$ & Number of computers & Unit \\
\hline \multirow[t]{2}{*}{$\begin{array}{l}\text { Energy-saving } \\
\text { concept }\end{array}$} & Energy saving lamp ratio & ESL & $\begin{array}{l}\text { The proportion of energy } \\
\text { saving lamp out of } \\
\text { total lamp }\end{array}$ & Percentage \\
\hline & Length of power use & PU & $\begin{array}{l}\text { The amount of time spent } \\
\text { on power use each day }\end{array}$ & Hour \\
\hline
\end{tabular}

Table 5. Model Summary.

\begin{tabular}{|c|c|c|c|c|c|c|c|c|c|}
\hline \multirow{2}{*}{$R$} & \multirow{2}{*}{$R^{2}$} & \multirow{2}{*}{$\begin{array}{c}\text { Adjusted } \\
R^{2}\end{array}$} & \multirow{2}{*}{$\begin{array}{l}\text { Std. Error of the } \\
\text { Estimate }\end{array}$} & \multicolumn{5}{|c|}{ Change Statistics } & \multirow{2}{*}{$\begin{array}{l}\text { Durbin } \\
\text { Watson }\end{array}$} \\
\hline & & & & $R^{2}$ Change & F Change & df1 & $\mathrm{df2}$ & Sig. F Change & \\
\hline 0.974 & 0.949 & 0.948 & 1301.62688 & 0.002 & 13.846 & 1 & 421 & 0.000 & 1.317 \\
\hline
\end{tabular}

Predictors: (Constant), IU, BH, PCA, NR, PU.

From Table 6, the following conclusions can be drawn: 
Table 6. Coefficients.

\begin{tabular}{|c|c|c|c|c|c|c|c|c|c|c|}
\hline \multirow[t]{2}{*}{ Variable } & \multicolumn{2}{|c|}{$\begin{array}{l}\text { Unstandardized } \\
\text { Coefficients }\end{array}$} & \multirow{2}{*}{$\begin{array}{c}\begin{array}{l}\text { Standardized } \\
\text { Coefficients }\end{array} \\
\text { Beta }\end{array}$} & \multirow[t]{2}{*}{$\mathbf{t}$} & \multirow[t]{2}{*}{ Sig. } & \multicolumn{3}{|c|}{ Correlations } & \multicolumn{2}{|c|}{$\begin{array}{l}\text { Collinearity } \\
\text { Statistics }\end{array}$} \\
\hline & B & Std. Error & & & & Zero-Order & Partial & Part & Tolerance & VIF \\
\hline IU & -4433.415 & 167.628 & -0.737 & -26.448 & 0.000 & -0.954 & -0.790 & -0.292 & 0.157 & 6.384 \\
\hline $\mathrm{BH}$ & -1927.197 & 174.641 & -0.152 & -11.035 & 0.000 & 0.219 & -0.474 & -0.122 & 0.644 & 1.553 \\
\hline PCA & 72.552 & 6.682 & 0.308 & 10.857 & 0.000 & 0.827 & 0.468 & 0.120 & 0.151 & 6.611 \\
\hline NR & 853.120 & 107.631 & 0.140 & 7.926 & 0.000 & 0.162 & 0.360 & 0.087 & 0.389 & 2.574 \\
\hline PU & 40.809 & 10.967 & 0.047 & 3.721 & 0.000 & 0.042 & 0.178 & 0.041 & 0.776 & 1.289 \\
\hline (Constant) & $17,061.611$ & 944.149 & & 18.071 & 0.000 & & & & & \\
\hline
\end{tabular}

Dependent Variable: Energy consumption.

According to the building condition item, the internal units, building height, and per capita construction area were inputted into the model. The internal unit for the residential building energy consumption is a negative impact, indicating that the smaller the units, the less the energy consumption of the family, because the small apartment building is relatively compact; building height for the family energy consumption is a negative impact, indicating that the high-rise building relatively multi-storey building energy consumption is less, because the high-rise building shape coefficient is smaller; per capita building area was positively correlated, indicating that the larger the per capita construction area, the higher the energy consumption, the greater the area of heating and cooling.

From the household condition, the number of occupants entered the final model. The number of residents is the positive factor, indicating that the more people living there, the greater the family energy consumption, because the greater the number of residents, the more intensive the use of energy, and the greater the need for household electricity and gas use.

From the energy-saving concept, the length of power use entered the final model. Power consumption and the final carbon dioxide emissions were positively correlated, indicating that the longer the use of household appliances, the more will be the energy consumption of the family. Therefore, it is necessary to strengthen the residents of the energy-saving education to make the occupants consciously reduce the unnecessary use of household appliances.

\section{Conclusions}

This study used eQUEST software to simulate the energy consumption of 8 types of residential buildings. To improve the simulation accuracy, real-time meteorological data based on field observation and actual energy consumption behaviour schedule were imported. Buildings in different construction age, different building height, different architecture forms, different apartment sizes were compared and a stepwise regression was used to calculate the main household energy impact variables. The following conclusions are summarized.

Residential buildings built in 1980s and 1990s in the case area consume more energy in space heating and cooling, and they need further energy-saving transformation. Water source heat pumps used in Guoaocun district had better energy-saving performance, and are suitable for residential applications throughout the study area. From the household and unit area energy consumption comparison point of view, the energy consumption per unit area in small-sized and high-rise buildings are lower. We recommend that small-sized units should be applied to normal apartment buildings and large-sized units should be applied to elite housing. Different energy price policies should be enacted to them. It is worth noting that high-rise building elevator energy consumption accounted for $5 \%$ of the total energy consumption in the case area. Therefore, small-sized high-rise apartment buildings should be encouraged to constructed appropriately and energy-saving strategies are required for public space in residential buildings. Household appliances accounted for second-largest proportion of total energy consumption, and the length of power use is one of most important impact variables of household energy consumption. Therefore, the application of energy-saving household appliances and the cultivation of good electricity habits is very important. 
Acknowledgments: This study was supported by the Natural Science Foundation Projects 'The Process and Influence Mechanism of Carbon Dioxide Emissions in Different Areas of Beijing Based on Flux Footprint' (No. 41771182), and 'Micro-scale research on stimulation and optimal regulation of carbon emission process in typical function area of metropolis' (No. 41271186).

Author Contributions: Yu Li and Chen Xu designed the research method; Yu Li and Chen $\mathrm{Xu}$ carried out the questionnaire survey; $\mathrm{Yu} \mathrm{Li}$, Chen $\mathrm{Xu}$ and Hao Cheng wrote the paper; Chen $\mathrm{Xu}$ and Xueting Jin analyzed the data; Chen $\mathrm{Xu}$ and Liang Yuan established the simulation models.

Conflicts of Interest: The authors declare no conflict of interest.

\section{References}

1. Doman, L.E.; Arora, V.; Hojjati, B.; Peterson, D. International Energy Outlook 2016; U.S. Energy Information Administration, Office of Energy Analysis, U.S. Department of Energy: Washington, DC, USA, 2016.

2. BP. Bp Statistical Review of World Energy 2015; BP: London, UK, 2016.

3. Fan, J.-L.; Liao, H.; Liang, Q.-M.; Tatano, H.; Liu, C.-F.; Wei, Y.-M. Residential carbon emission evolutions in urban-rural divided China: An end-use and behavior analysis. Appl. Energy 2013, 101, 323-332. [CrossRef]

4. Dall'O', G.; Galante, A.; Torri, M. A methodology for the energy performance classification of residential building stock on an urban scale. Energy Build. 2012, 48, 211-219. [CrossRef]

5. Swan, L.G.; Ugursal, V.I. Modeling of end-use energy consumption in the residential sector: A review of modeling techniques. Renew. Sustain. Energy Rev. 2009, 13, 1819-1835. [CrossRef]

6. Fan, J.-L.; Zhang, Y.-J.; Wang, B. The impact of urbanization on residential energy consumption in China: An aggregated and disaggregated analysis. Renew. Sustain. Energy Rev. 2017, 75, 220-233. [CrossRef]

7. Miao, L. Examining the impact factors of urban residential energy consumption and $\mathrm{CO}_{2}$ emissions in China-Evidence from city-level data. Ecol. Indic. 2017, 73, 29-37. [CrossRef]

8. Hu, S.; Yan, D.; Guo, S.; Cui, Y.; Dong, B. A survey on energy consumption and energy usage behavior of households and residential building in urban China. Energy Build. 2017, 148, 366-378. [CrossRef]

9. Sukarno, I.; Matsumoto, H.; Susanti, L. Household lifestyle effect on residential electrical energy consumption in Indonesia: On-site measurement methods. Urban Clim. 2017, 20, 20-32. [CrossRef]

10. Abanda, F.H.; Byers, L. An investigation of the impact of building orientation on energy consumption in a domestic building using emerging bim (building information modelling). Energy 2016, 97, 517-527. [CrossRef]

11. Sadeghifam, A.N.; Zahraee, S.M.; Meynagh, M.M.; Kiani, I. Combined use of design of experiment and dynamic building simulation in assessment of energy efficiency in tropical residential buildings. Energy Build. 2015, 86, 525-533. [CrossRef]

12. La Fleur, L.; Moshfegh, B.; Rohdin, P. Measured and predicted energy use and indoor climate before and after a major renovation of an apartment building in Sweden. Energy Build. 2017, 146, 98-110. [CrossRef]

13. Mastouri, H.; Benhamou, B.; Hamdi, H.; Mouyal, E. Thermal performance assessment of passive techniques integrated into a residential building in semi-arid climate. Energy Build. 2017, 143, 1-16. [CrossRef]

14. Fuertes, G.; Schiavon, S. Plug load energy analysis: The role of plug loads in leed certification and energy modeling. Energy Build. 2014, 76, 328-335. [CrossRef]

15. Zhu, Y. Applying computer-based simulation to energy auditing: A case study. Energy Build. 2006, 38, 421-428. [CrossRef]

16. Richman, R.; Simpson, R. Towards quantifying energy saving strategies in big-box retail stores: A case study in Ontario (Canada). Sustain. Cities Soc. 2016, 20, 61-70. [CrossRef]

17. Kim, B. Improvement of indoor thermal environment through solar heat gain loads reduction for an office building. J. Archit. Inst. Korea Plan. Des. 2010, 26, 313-320.

18. Yu, J.; Yang, C.; Tian, L. Low-energy envelope design of residential building in hot summer and cold winter zone in China. Energy Build. 2008, 40, 1536-1546. [CrossRef]

19. Wang, W.; Wu, J. Energy consumption analysis method of airport terminal buildings based on equest. J. Civ. Aviat. Univ. China 2013, 31, 34-37.

20. Wu, C.L.; Zhou, H.Z.; Yin, B.; Yan, J.J. Energy saving analysis of air conditioning system for one office building based on equest simulation. Build. Energy Environ. 2013, 32, 56-58.

21. Yin, R.; Xu, P.; Shen, P. Case study: Energy savings from solar window film in two commercial buildings in Shanghai. Energy Build. 2012, 45, 132-140. [CrossRef] 
22. Yuan, L.; Li, Y. The Study of Large-Scale Public Buildings' Carbon Dioxide Emission of Olympic Central Area in Beijing; The University of Chinese Academy of Sciences: Beijing, China, 2015.

23. Cui, Y.; Yan, D.; Hong, T.; Xiao, C.; Luo, X.; Zhang, Q. Comparison of typical year and multiyear building simulations using a 55-year actual weather data set from China. Appl. Energy 2017, 195, 890-904. [CrossRef]

24. Kwak, Y.; Huh, J.-H. Development of a method of real-time building energy simulation for efficient predictive control. Energy Convers. Manag. 2016, 113, 220-229. [CrossRef]

25. Emery, A.F.; Kippenhan, C.J. A long term study of residential home heating consumption and the effect of occupant behavior on homes in the pacific northwest constructed according to improved thermal standards. Energy 2006, 31, 677-693. [CrossRef]

26. Iwashita, G.; Akasaka, H. The effects of human behavior on natural ventilation rate and indoor air environment in summer-A field study in southern Japan. Energy Build. 1997, 25, 195-205. [CrossRef]

27. Pettersen, T.D. Variation of energy consumption in dwellings due to climate, building and inhabitants. Energy Build. 1994, 21, 209-218. [CrossRef]

28. Aksoezen, M.; Daniel, M.; Hassler, U.; Kohler, N. Building age as an indicator for energy consumption. Energy Build. 2015, 87, 74-86. [CrossRef]

29. Brounen, D.; Kok, N.; Quigley, J.M. Residential energy use and conservation: Economics and demographics. Eur. Econ. Rev. 2012, 56, 931-945. [CrossRef]

30. Beijing "12th five-year" building energy efficiency standards will be increased by $15 \%$. Build. Energy Effic. 2013, 41, 62.

31. Caputo, P.; Costa, G.; Ferrari, S. A supporting method for defining energy strategies in the building sector at urban scale. Energy Policy 2013, 55, 261-270. [CrossRef]

32. Mastrucci, A.; Baume, O.; Stazi, F.; Leopold, U. Estimating energy savings for the residential building stock of an entire city: A gis-based statistical downscaling approach applied to rotterdam. Energy Build. 2014, 75, 358-367. [CrossRef]

33. Liu, X.; Sweeney, J. Modelling the impact of urban form on household energy demand and related $\mathrm{CO}_{2}$ emissions in the greater Dublin region. Energy Policy 2012, 46, 359-369. [CrossRef]

34. Yang, T.; Chen, H.; Zhang, Y.; Zhang, S.; Feng, F. Towards low-carbon urban forms: A comparative study on energy efficiencies of residential neighborhoods in Chongming eco-island. Energy Procedia 2016, 88, 321-324. [CrossRef]

35. Estiri, H. Building and household $x$-factors and energy consumption at the residential sector: A structural equation analysis of the effects of household and building characteristics on the annual energy consumption of us residential buildings. Energy Econ. 2014, 43, 178-184. [CrossRef]

36. Yan, F.; Li, H.; Zheng, H. Research on factors of Beijing's building carbon emissions. Ecol. Econ. 2016, 72-75.

37. $\mathrm{Pu}, \mathrm{Q}$. Research on Prediction Model and Influencing Factors of Urban Residential Building Energy Consumption. Ph.D. Thesis, Chongqing University, Chongqing, China, 2012.

38. National Development and Reform Commission. Notifications of the Pilot Work of the Second Batch of Low Carbon Provinces and Low Carbon Cities by the National Development and Reform Commission; National Development and Reform Commission: Beijing, China, 2010.

39. Duan, K.; Ren, J.; Zhang, J.; Wang, Z.; Cui, X.; Li, J.; Li, J. Effectiveness test and economic energy efficiency analysis of energy saving renovation of residential buildings in Beijing. Constr. Technol. 2012, 41, 35-38.

40. Opinions on the Implementation of Comprehensive Rehabilitation of Old Residential District in Beijing; Beijing Municipal People's Government: Beijing, China, 2012.

41. Li, Z.W. Beijing Plans to Expand the Scope of the Old District Transformation 5 Types of Old District Were Added; Beijing Youth Daily: Beijing, China, 2016.

42. Energy Performance of Lifts and Escalators_Part 1: Energy Measurement and Conformance; ISO/DIS 25745-1:2008; International Organization for Standardization: Geneva, Switzerland, 2008. Available online: https:/ /infostore. saiglobal.com/en-au/Standards/NEN-EN-ISO-25745-1-2008-1074753/ (accessed on 3 December 2017).

43. Beijing City "13th Five-Year" Period Civil Building Energy Development Planning Beijing Municipal Committee of Housing and Urban Rural Development; Beijing Municipal Development and Reform Commission: Beijing, China, 2016.

(C) 2017 by the authors. Licensee MDPI, Basel, Switzerland. This article is an open access article distributed under the terms and conditions of the Creative Commons Attribution (CC BY) license (http:// creativecommons.org/licenses/by/4.0/). 